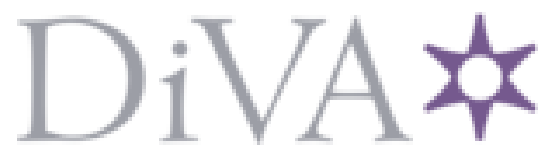

http://www.diva-portal.org

\title{
Postprint
}

This is the accepted version of a paper published in The History of the Family. This paper has been peer-reviewed but does not include the final publisher proof-corrections or journal pagination.

Citation for the original published paper (version of record):

Junkka, J., Edvinsson, S. (2016)

Gender and fertility within the free churches in the Sundsvall region, Sweden, 1860-1921.

The History of the Family, 21(2): 243-266

http://dx.doi.org/10.1080/1081602X.2015.1043929

Access to the published version may require subscription.

N.B. When citing this work, cite the original published paper.

Permanent link to this version:

http://urn.kb.se/resolve?urn=urn:nbn:se:umu:diva-105082 


\section{Gender and fertility within the free churches in the Sundsvall region, Sweden, 1860-1921}

\author{
Johan Junkka* \\ Department of historical, \\ philosophical and religious studies \\ Umeå university, Sweden
}

\author{
Sören Edvinsson ${ }^{\dagger}$ \\ Centre for Population Studies \\ Umeå university, Sweden
}

The Version of Record of this manuscript has been published and is available in History of the Family 2015 http://www.tandfonline.com/10.1080/1081602X.2015.1043929.

\footnotetext{
*Email address: johan.junkka@umu.se

${ }^{\dagger}$ Email address: soren.edvinsson@umu.se
} 


\begin{abstract}
The role of secularization in the European fertility decline has been of interest to demographers, who often explore the relationship on a macro-level or by identifying religious affiliation by proxy. However, the relationship has not been thoroughly studied on an individual level utilizing indicators of personal religious conviction and affiliation. The aim of the present article is to examine reproductive practices by religious affiliation in order to understand the impact of secularization on fertility decline. This is accomplished using event history analysis of longitudinal parish register data from Sundsvall $(1860$ - 1921) where religious affiliation is identified on a family level. Reproductive practices are analysed using cohort TFR, descriptive statistics and Cox proportional hazard regressions. Free-church affiliates had, overall, a higher probability of having another child than did affiliates to the state church. However, these differences decreased over time, and as fertility dropped throughout society free-church affiliates showed the strongest significant reduction in probability of another birth. This indicates that over time, within the free churches, ideas about respectability and restraint came to mean that birth control, in the form of abstinence within marriage, became an important practice in the formation of gendered religious identities - leading to a relatively early decrease in fertility.
\end{abstract}

Keywords: fertility decline; religion; gender; secularization 


\section{Introduction}

At the onset of the fertility transition in the late 19th century, Sweden was not only experiencing profound economic and social change, but also religious change - secularization. The Lutheran state church, whose religious culture legitimized the predominant social structure, was losing its authority given the decrease in involvement in state church activities and attendance at state church rituals. At the same time, religious and secular popular movements were growing, and with them competing cultures of gender, sexuality and fertility. The process enabled new ways of organizing society and family. The role of religion and secularization in the European fertility decline has been of great interest to historical demographers. Questions concerning religious differences have been thoroughly explored and discussed, such as the early adoption of fertility control by the Jewish population (Derosas, 2006; Knodel, 1974; Livi-Bacci, 1986), the dichotomous views of Catholic and Protestant fertility (McQuillan, 1999, 2006; Schellekens \& Poppel, 2006) or the adoption of fertility control through spacing behaviour within religious groups (Anderton \& Bean, 1985; Heaton, 1986). Secularization has been argued to be an important factor for the pace of fertility decline both in Sweden and the rest of the western world, where free-churches andliberal denominations has been associated with lower fertility rates. (Benz, 2006; Hacker, 1999; Larsson, 1984; Lockridge, 1983). However, the relationship between secularization and fertility has often been explored on a macro-level or by identifying religious affiliation by proxy. The relationship between secularization and fertility decline has not been thoroughly studied on an individual level utilizing indicators of religious conviction.

The aim of the present article is to examine reproductive practices by religious affiliation in order to understand the impact of secularization on fertility decline. We argue that previous research has been limited by theoretical conceptions that view secularization as primarily a dichotomous process, moving from religious devotion to rationality. Drawing upon recent theoretical perspectives from religious studies, we define secularization as a process of increased cultural competition and emphasize a gender perspective, we also see this process as resulting in a plethora of religious conceptions such as the free churches. Thereby we especially focus on gender and reproductive practices within the free churches in an effort to gain knowledge about the mechanisms underlying the possible effect of secularization on fertility decline. The primary goals of the present article is thus to asses the free churches ability to affect reproductive practices and secondly to estimate changes and differences in reproductive practices by religious affiliation. Using longitudinal individual level data from Sundsvall for the period 1860-1921 combined with family-level information on religious affiliation we can distinguish between reproductive practices of state church and free-church affiliates. Furthermore, by using a combination of descriptive statistics and event history analysis we can test the effect of religious affiliations on 
reproductive practices before and during the fertility decline.

\section{Theory and previous research}

Demographers and historians have long studied the relationship between religious change and fertility. The results of the Princeton European Fertility Project (PEFP), although criticized, questioned the explanations of classical demographic transition theory, according to which economic and social modernization were the determinants of fertility decline. Instead the project participants emphasized the importance of cultural factors (Watkins, 1986), secularization thus being viewed as a driving force. Trying to create a holistic framework of fertility change, Ansley Coale defines three preconditions for the fertility transition: "Fertility must be within the calculus of conscious choice", "Perceived social and economic circumstances must make reduced fertility seem advantageous" and "Effective techniques of fertility reduction must be available" (A. Coale, 1973, p. 65). In their contribution to the PEFP, Lesthaeghe and Wilson define secularization as "[...] turning away from the Christian ethics and a movement toward secular ideas" (Lesthaeghe \& Wilson, 1986, p. 270). From their point of view, it was through secularization that fertility became within the calculus of conscious choice, it was Christian ethics that made fertility control inconceivable and it was through secular ideas that rational reproductive decisions could be made (Lesthaeghe \& Wilson, 1986).

In other works Lesthaeghe broadens his definition of secularization to include: a decrease in belief, emancipation, declining adherence to organized religion, the individualization of religion and institutional secularization combined with conservative private morality (Lesthaeghe, 1980; Lesthaeghe \& Surkyn, 1988). Others do not define secularization explicitly, sometimes using the term interchangeably with secularism (the movement striving for the separation of church and state). However most, implicitly or explicitly, refer to some form of de-Christianization on a personal or societal level - a process that results in making fertility control conceivable (Gauvreau, 2006; Kok \& Van Bavel, 2006; Praz, 2006b; Schellekens \& Poppel, 2006). Yet the existence of pre-transitional fertility control has been shown empirically (Bengtsson \& Dribe, 2006; Kolk, 2011; Reher \& Sandström, 2015; Sandström \& Vikström, 2015; Van Bavel, 2004b; Van Bavel \& Kok, 2010), thus problematizing the dichotomous view of the fertility transition as a shift from "natural" fertility without deliberate fertility control, only regulated by Malthusian preventive checks (Malthus, 1926), to controlled fertility as defined by Henry (1961).

The dichotomous view of secularization has also been criticized by Lynch (2006), who highlights continuity rather than a revolutionary shift. From sociology of religion, we get another perspective. Beckford (2003) argues that it is unproductive to see religion as a static object, containing certain attributes, when religion is a social 
construction that is constantly changing. In this view, it is at times when the meaning of religion has been disputed, constructed and debated that it is of special interest. Secularization is such a process. Yet secularization was not a simple transition from religious conviction to rational thought, but rather a process whereby the meaning of religion was challenged and changed. When the church no longer could uphold social discipline and control, it opened up for other interpretations including rationality and deism, but also alternative forms of Christian associations (McLeod, 2000). In this sense, secularization refers to a process of increased cultural competition.

With this in mind, instead of viewing secularization as a process that made fertility control conceivable, it is more fruitful to view it from the perspective of increased competition and to focus on how reproductive practices were performed and perceived within a certain secular or religious cultural context. The sharp distinctions between Jewish, Catholic and Protestant fertility have also been problematized, as studies has shown the great internal variations between different subgroups (Benz, 2006; Derosas, 2006). Recent studies of secularization have highlighted the importance of gender. They have done this quantitatively by referring to the increasing number of women compared to men who participated in religious rites, and qualitatively by referring to the reversal of representations of piety and sin. While manliness previously was at the centre of piety, piety came to be a part of femininity, a shift from seeing women as the heirs of Eve to men as the gender more easily corrupted by sin (Brown, 2009). Religious institutions became places where women could act outside the boundaries of family life in charity, mission or education - separate spheres where women could hold authority (Davidoff \& Hall, 1987; Pasture, 2012). At the same time, this moral power came with requirements of sexual disempowerment, celibacy or at least sexual restraint. Although men were considered more easily corrupted, women were held responsible for controlling their spouses behaviour. It was the woman's role to care for the salvation of her family and kin. Secularization, within these settings enabled empowerment without threatening the gender power structure, at least not as much as the emancipation movement did. Manliness, at the same time, emphasized men's role as fathers, husbands and workers, promoting acts of charity and restraint, but also the virile masculinity of heroic missionaries (Pasture, 2012).

Like religion, reproductive practices are closely linked to the social construction of gender. Biologically, only women can have children, although, historically, this has required a man's participation. Socially, women's role within society has been tied to reproductive work (Greenhalgh, 1995). (Butler, 2004) argues that it is through performative practices that differences between people are produced, reproduced and understood. Performance of reproductive behaviour is not only affected by gender, it is also part of how actors produce gender and social order (Carter, 1995). This has also been shown in research that has taken gender into account when studying fertility change. Qualitative research in the Swedish context has shown that the construction of gender roles and gender relations was important for the 
adoption of birth control. Reproductive decisions were influenced by the idea of respectability, that is, what was considered respectable behaviour on the part of men and women with regard to family and sexuality issues. Small families came to be associated with respectability, and family limitation was the means of conforming to gender norms (Kling, 2007, 2010). Studies of the relationship between class and reproductive practices have emphasized the role of how gender was embedded in a certain community for the pace of fertility decline (Szreter, 1993; Warg, 2002). In her study of the Swiss fertility decline, Praz (Praz, 2006a, 2006b, 2007, 2007, 2009) promotes the idea of gendered religious cultures. By arguing for and testing how differences in the construction of gender between the Protestant and Catholic cantons affected the pace of the fertility decline, Praz claims that merely living within a context where manliness, femaleness and sexuality were perceived and performed differently affected reproductive practices. We propose that by linking religious affiliation and religiosity on a family level we can test this relationship more directly.

In conclusion, secularization was not a simple process of decline in organised religion. Using the insights of religious historians we propose another perspective on secularization where the process entailed that the meaning of religion was challenged and changed - a process which the free churches was an integral part of. These new religious cultures enabled new ways of conceptualising gender and gender relations that emphasized, among others, sexual restraint and an empowerment of women when it came to issues of morality. Which in turn fostered a culture where small families and family control where conceivable and even desirable if this also was a societal norm.

However, the effect of religion on fertility was not limited to norms and practices. McQuillan has shown the importance of other factors and has formulated three preconditions for when religion affects fertility. First, religious communities must have established norms and practices concerning behaviours that affect fertility. They also need to have the means to spread these ideas by having some form of power within society. Finally, people need to have a strong personal religious conviction (McQuillan, 2006). By focusing on practices, power and identity within a religious culture, the analysis incorporates the structure, the individual and their relationship when assessing the strength of possible religious effects on reproductive practices. Furthermore, as McQuillan's framework is focused on analysing the strength of the religious effect on fertility rather than the outcome, he does not assume any specific consequence of a decrease in any of the preconditions, other than a decrease in the effect of a religion on fertility. We use the framework to separate the effect of changes in power, such as social control, and changes in religiosity from changes in gender norms and practices, which we are primarily interested in as indicators of secularization. In the next section, we explore the context of the study, especially focusing on the first two preconditions of the framework: practices and power relations within the free churches. 


\section{Context}

Since the early modern period in Sweden, the Lutheran church had been an integrated part of the consolidation of power and state-building process. The parish priest was a central figure not only regarding religious issues, but he also had political power in local councils. Attendance at communion and parish catechetical interrogations was compulsory, and baptisms, weddings and burials were important religious rituals for individuals and communities. The separation of state and church was rendered irreversible when the municipal regulation was implemented in 1862. Legislatively, compulsory participation in communion was repealed in 1863 and the prohibition of gathering for religious purposes outside the church in 1868. Finally, through the Dissidents Act of 1873, citizens were able to leave the Lutheran state church upon entering another authorized church (Bäckström, 1999; Lundkvist, 1977).

During the 19th century, the Sundsvall region was economically and socially diverse, with the small town of Sundsvall placed on the shore of the Gulf of Bothnia, surrounded by coastal parishes that, starting in the 1870s, experienced rapid industrialization fuelled by the expanding sawmill industry. The inland of the region was characterized by rural agrarian societies with close connections to the town and coastal parishes, as seen in Figure 1. From a quantitative perspective, we can look at secularization as participation in church rites such as communion and catechetical examinations. Attendance at communion in the region started to decrease from 70 percent in 1855 to less than 10 percent in 1890. Attendance at the catechetical examinations started to decrease from 60 percent in the 1840s to less than 10 percent in the 1890s. Attendance was lowest among the young working classes in the industrialized and urban areas, and starting in the 1860s women's attendance grew to be higher than men's (Bäckström, 1999). In terms of involvement in state church activities, the Sundsvall region experienced a strong secularization process during the second half of the 19th century, to some extent spurred by the revival movement and growth of free churches.

The revival movement refers to a larger religious movement that re-emphasized the reformation view on Christianity (salvation by faith alone, repentance and personal confession). Free churches were those revival groups that formed their own congregations separate from the Swedish state church. The free churches are the oldest group among the major Swedish popular movements, and were followed by the temperance movement and the labour movement (Gustavsson, 1985; Lindberg, 1985; Lundkvist, 1977). The term popular movements has a distinct meaning in a Swedish context which can be equated to the international term "voluntary associations". Associations who strove to promote a common interest, were independent of the state and whose members joined voluntarily and worked for the organization on their spare time. Within this definition falls not only the temperance movement, and political parties but also the free-churches (Lundkvist, 1980; Sills, 1968). The 
revival movement reached Sundsvall at an early stage. The first free church, a Baptist congregation was established in 1855 with around 200 members. Evangeliska fosterlandsstiftelsen (Swedish Evangelical Mission), an intra-church revival movement, was established in 1857. After internal struggles in 1877, Svenska missionsförbundet (The Swedish Missionary Church) broke loose and established its own congregation. The Methodist Church was established in 1879 and the Salvation Army in 1885 (Bäckström, 1999).
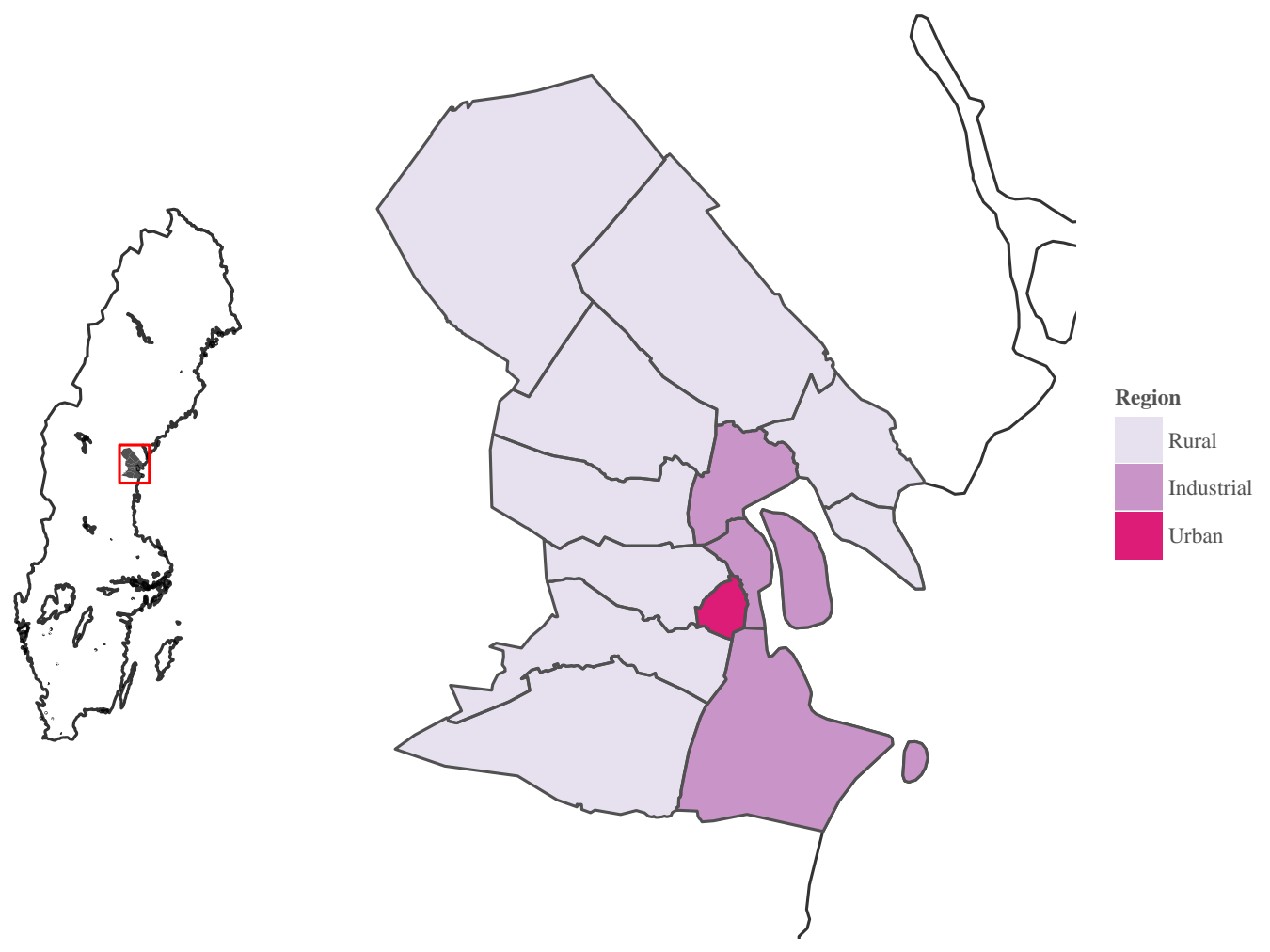

Figure 1: The Sundsvall region

From the membership lists collected in the Popular movements archive (1881-1950) and made available by the Swedish National Database Service (Andrae \& Lundkvist, 1998; Lundkvist, 1977), we can see membership development in the Sundsvall region displayed in Figure 2. Because the reporting was not always conducted annually for all free churches, missing values are imputed by linear interpolation. ${ }^{1}$ In 1881 , the free churches had a membership of 2,071 and collectively grew their membership to 4,887 after 1910 . The movement is also characterized by high member turnover,

\footnotetext{
${ }^{1}$ Through na.approx form the zoo package (Zeileis \& Grothendieck, 2005)
} 


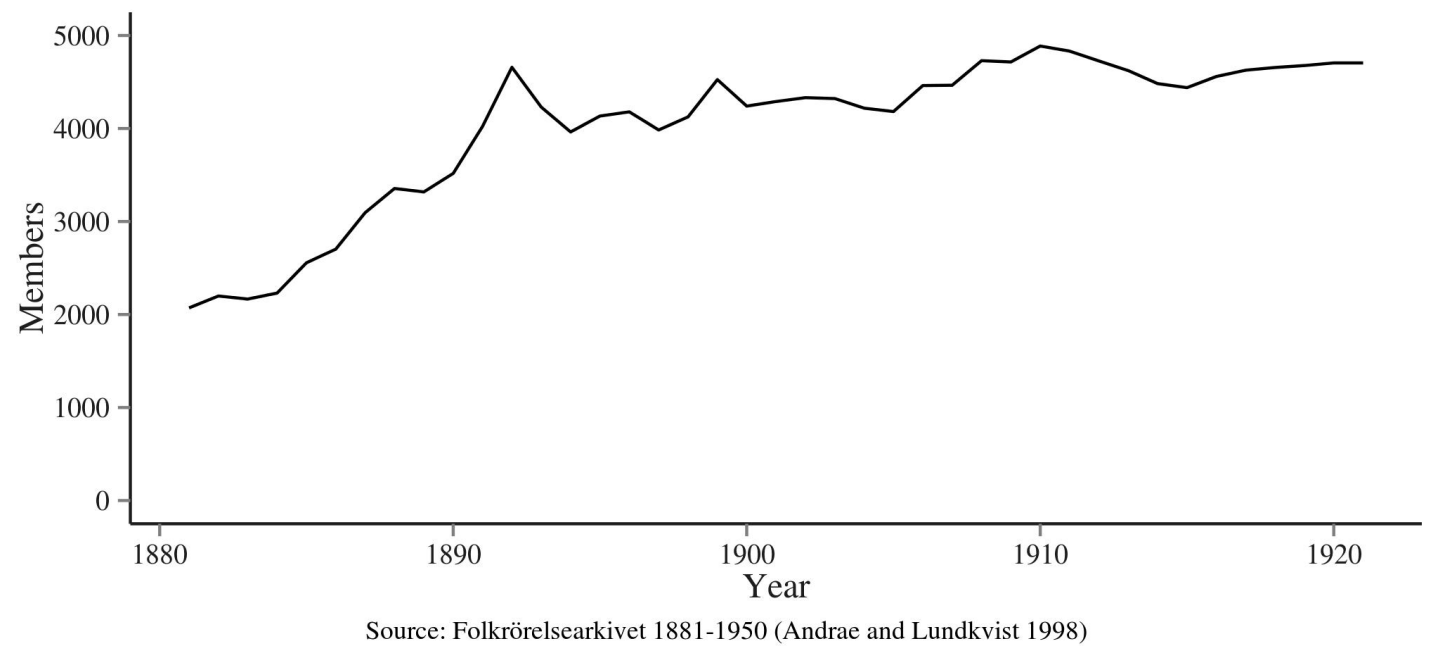

Figure 2: Free-church membership in Sundsvall region 1881-1930

which can be seen in the sharp increase in 1892, related to the sudden Baptist revival the year before, when for example 234 persons were baptized in the town of Sundsvall (Johansson, 1997).

In Sweden, male members dominated the popular movements during the period 1850-1920, especially the unions but also the temperance movement, which had around 60 percent male members. The exceptions were the free churches, where women constituted around two thirds of the membership (@ Lundkvist, 1977). The Sundsvall region conforms well to this pattern; between 60-75 percent of members were women (Kennerberg, 1996). With women having the numerical upper hand, the free churches were also dependent on women's work for the day-to-day practical operations of the organization. Women organized themselves in sewing circles, providing economic funding through bazaars and fundraising. Men came to dominate the formal decision-making bodies, although in some congregations women did sit as board members. The free churches in Sundsvall were indeed organizations in which women could take an active role in religious work, caring for the salvation of family and kin (Åberg, 1995; Kennerberg, 1996).

To assess the free churches ability to affect reproductive practices we use McQuillan's framework. First, when it comes to explicit norms about reoroductive practices, birth control within marriage was not seen as problematic within the free churches, rather it was promoted. When debating with the neo-Malthusian doctor Wiksell, proponents from the Lutheran state church attested that men should apply the same principles of chastity as women do. It was a woman's duty to persuade her husband to discipline his sexuality. This was birth control through abstinence (Hammar, 1999). The same attitudes can be seen within the free churches, during the debate 
about the contraceptive law of 1910 . The use of contraceptives within marriage was even seen by the younger generations as acceptable, however abstinence was universally promoted by all free churches (Kristenson, 1997).

Regarding McQuillan's second precondition the means by which these practices and norms were spread and promoted within the free churches can be found within a system of congregational discipline and control. The Baptist and Swedish Missionary Church congregations were largely autonomous organizations until the turn of the century; this was also the case in the Sundsvall region. These churches chose their own board members, wrote their own statutes and regulations based on their interpretations of the scriptures. While ministers and board members were almost exclusively male, questions and debate topics were brought up at general meetings, where in most congregations both male and female members had the right to speak and sometimes even vote. Discipline and control were maintained by the whole congregation, and the behaviour of all members was of the utmost importance and closely monitored. The members should behave respectably and in a controlled manner both in public and in private by conforming to gendered codes concerning premarital relations, dress, work and consumption. Violations were brought up by members at general meetings, debated and, when needed, punished through warnings, by stripping of communal rights, such as participation in communion, or by exclusion from the congregation. Of special interest were questions of religious as well as sexual morality, such as when a man who had made inappropriate sexual advances towards female members was excluded, or when women who cut their hair too short were warned (Åberg, 1995; Kennerberg, 1996). These were norms and practices that promoted sexual restraint both for men and women which indirectly could effect reproductive decisions.

The situation within the free churches fulfilled the first two preconditions of McQuillan's schema. There were clear gender norms and divisions of labour that could affect fertility, and the free churches had a rigid system of producing and reproducing these norms and practices through congregational discipline and control. In the next section, we will also demonstrate how personal religious conviction is identified and connected on a family level.

\section{Data}

The primary source is digitized parish records, from the database POPUM, which is part of the Demographic Database in Umeå, for the Sundsvall region 1860-1900, a longitudinal database that makes it possible to analyse life events on an individual level (P. Vikström, Edvinsson, \& Brändström, 2002). The sample consists of all women who married during the period 1860-1889 and their families. To capture the start of the fertility transition, the data are complemented manually by a cohort 
of women born 1869-1871 who are followed in the parish registers as far as 1921 . The parish registers allow us to continuously follow individuals throughout their lives as long as they remained in one of the registered parishes. The information on individuals in the parish registers is linked and the family relations are identified. Thus, we can reconstruct the reproductive history of families in the available parishes. Furthermore, the Swedish parish registers allow us to keep individuals under complete observation until they die or leave the parish, thus giving us reliable end dates for all life courses. The number of parishes in the digitized region is 18, whereof 17 are used in this study.

The data are divided into three cohorts, two marriage cohorts 15 years in length, married before and after 1875, and the birth cohort of women born 1869-1871. The study starts observing the sample from the date of the women's first marriage until the observable reproductive life course ends. In Figure 3, the distribution of the end and start years of observation is shown by cohort and religious affiliation. Here we see that the first marriage cohort covers reproductive histories that begin in the 1860s and end as late as the 1890s, while the later marriage cohort captures those who start after 1875. Period fertility did not start to decline until around 1900, thus we can assume that these cohorts capture pre-transitional reproductive behaviour. The birth cohort, on the other hand, captures reproductive histories that start around 1890 and end as late as 1921; it is this cohort that experienced the onset of the fertility decline in the Sundsvall region. As the similarities in distribution between end and start dates is largest between the first marriage cohort and the birth cohort, these are the primary comparison groups. Furthermore, the figure shows the similarities in distribution between religious affiliations. The number of complete reproductive histories is low compared to the total number of marriages included in the study, as seen in Table 1.

\begin{tabular}{lrrr}
\hline Group & Marriages & Births & Complete marriages \\
\hline Marriage cohort 1 & 3941 & 11558.00 & 1777 \\
Marriage cohort 2 & 5166 & 10914.00 & 436 \\
Birth cohort & 234 & 623.00 & 70 \\
State & 8183 & 19426.00 & 2045 \\
Free-church & 1158 & 3669.00 & 238 \\
Total & 9341 & 23095.00 & 2283 \\
\hline
\end{tabular}

Table 1: Number of events and marriges by cohort

Historical demographers have always found it difficult to capture and analyse religion, as many regions are religiously homogeneous and labels such as Catholic or Protestant do not say anything about personal convictions. Proxy variables, such as naming conventions (Hacker, 1999) or socialist votes in elections (Larsson, 1984; Lesthaeghe \& Wilson, 1986), have been used to capture conviction or secularization. Often 


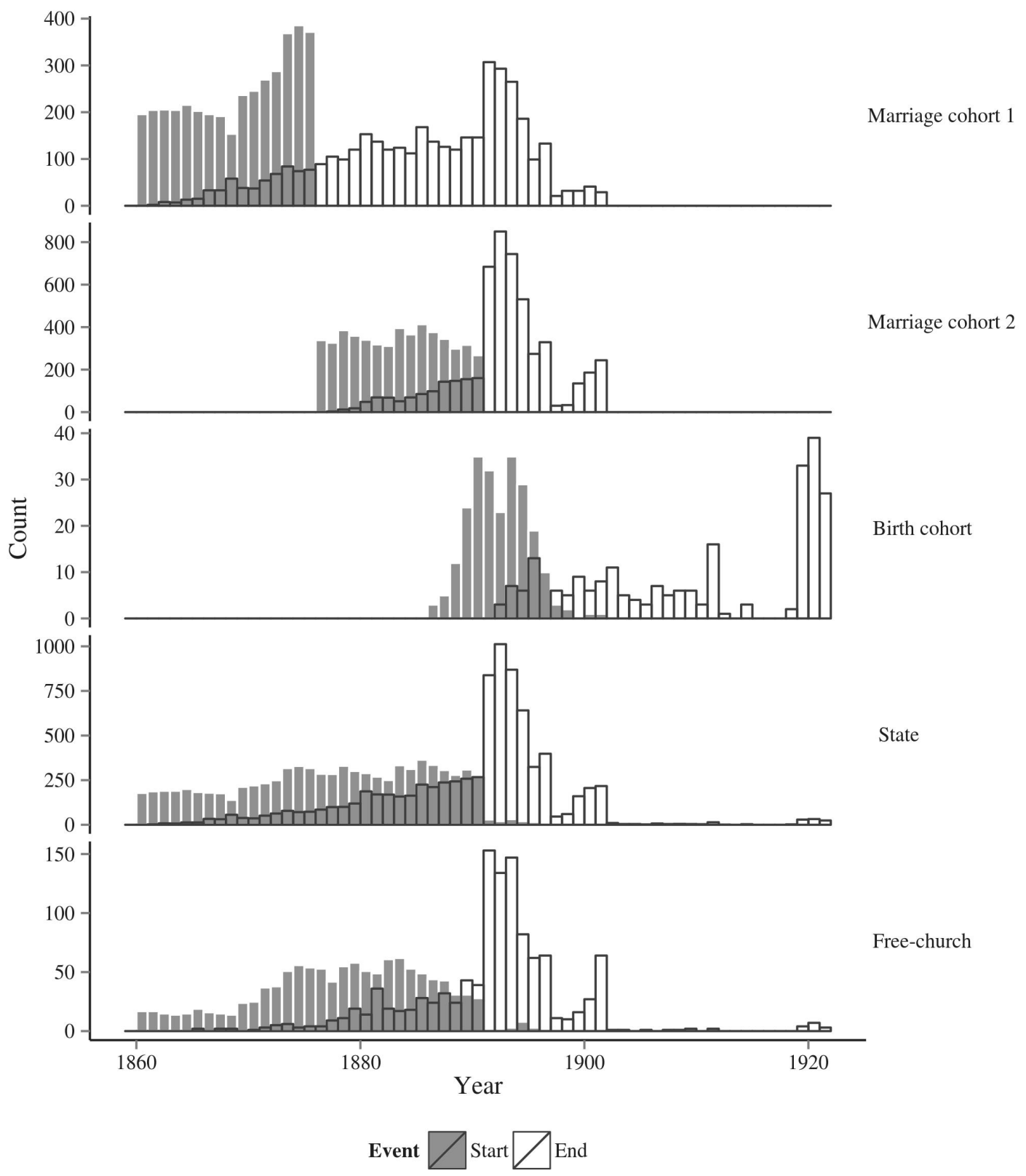

Figure 3: Distribution of observation start and end dates by affiliation and cohort 
researchers have to settle for contextual information on religious beliefs (McQuillan, 2006; Praz, 2006b). In Sweden the parish record consists of the total population regardless of religious affiliation. Furthermore, in Sundsvall and in Sweden as a whole, the priests made a note in the baptism register of whether the child was not baptized in the Lutheran state church, which they were obliged to by church regulations (Kyrkoskrifningskomitén, 1891, §6). Notes are found such as "Not baptized", "Father refuses to let the child be baptized" or even "Mother is a Baptist". Using these notes, the religious affiliation of the parents can be reconstructed.

All couples are assumed to be affiliated with the Lutheran state church if no other information proves the contrary. Contrary information includes notes directly identifying the free-church affiliation or notes expressing the family's refusal to baptize the child, as this would indicate that at least one of the parents was a member of a free church. Notes stating "Not baptized" are not considered sufficient information to identify the parents as affiliated with a free church, as they could also be the result of a child dying before baptism. Ambiguous notations are further verified through notations in the catechetical examinations. As the definition rests on the assumption that all individuals who cannot be explicitly identified as members of a free church were affiliated with the Lutheran state church, the chance of being identified as a free-church member increases the more children they had. This means that there is a chance that free-church families that had fewer children will not be identified in the sources and thereby that couples with more observed births will be overrepresented within the free-church group. However, as the priest was obliged to record parishioners who were members of another church, which became evident when they refused to baptize their child in the Lutheran state church (Kyrkoskrifningskomitén, $1891, \S 6)$, the risk of missing free-church families with few observed births is low.

The information in the birth records is considered static information on family-level affiliation and not as an event. The affiliation effect on fertility is thus not the effect of converting from one faith to another, but rather an indicator of religious conviction and a certain world view on the part of the parents that is less likely to change from one birth to another. Consider also that the priest's note "The father refuses to baptize the child"2 is a strong statement indicating an active decision on the part of the father (or/and mother) to defy the pastor and not baptize the child in the state church. Not so long ago, refusals to baptize a child had been met with forced baptism, and the very strong tradition of baptizing the child within the state church would have been difficult to break.

\footnotetext{
${ }^{2}$ Original Swedish: "Fadern vägrar låta döpa barnet".
} 


\section{Method}

In the present study, we are primarily interested in birth control practices. The actual practices cannot be ascertained through traditional historical demographic sources, but the demographic outcomes of these practices can, such as age at marriage, agespecific marital fertility rates and intervals between births. Essentially we are testing the effect of free-church affiliation on total fertility rate, woman's age at marriage and the timing of another birth. Although the number of complete reproductive histories is low, as seen in Table 1, the longitudinal data combined with a reliable exit date allow us to calculate age-specific and total cohort fertility rates. For cohort TFR, the number of events (births) experienced within an age group is divided by the total exposure time "women-years at risk" (Bhrolcháin, 2011; Broström, 2014; Hinde, 1998). Marriage age is analysed using descriptive statistics, however because the birth and marriage cohorts were sampled using different methods, only internal comparisons are possible.

To analyse the effect of religious affiliation on fertility timing, we estimate the effects through event history analysis using the statistical programing language $\mathrm{R}$ ( R Core Team, 2014) and the survival package (Therneau, 2014; Therneau \& Grambsch, 2000). ${ }^{3}$ The affiliation effect is analysed bivariately using Nelson-Aalen plots and multivariately using Cox proportional hazard regressions. With the help of Nelson-Aalen visualizations, we can explore differences in the hazard function of the timing of another birth counted from a previous birth. Cox proportional hazard regressions are well suited for multivariate analyses of reproductive behaviour, as we can handle censoring, allowing us to include all observed births after marriage until one of the spouses dies, the woman reaches 45 years of age or the couple can no longer be followed in the sources. As we are interested in behaviours over the whole reproductive life course, we use a conditional counting process. This entails that we use all observed closed and open birth intervals after the first birth and that time to event is measured from the first observed birth after marriage and continues until end of observation. The risk is then stratified by parity to account for parity dependence. The risk of having another birth is thereby conditional on total exposure time and parity. As we include multiple births per couple we adjust the models for what is unknown but specific to a man and a woman in a certain marriage, the model is thereby clustered by unique couple. Finally, because this process takes into account all births to estimate the effects, the model becomes more robust, which is of importance when considering the small sample size of the birth cohort (Prentice, Williams, \& Peterson, 1981). ${ }^{4}$ Furthermore, to overcome problems with the proportional hazard assumption, the first nine months are not included in

\footnotetext{
${ }^{3}$ For a longer explanation of event history analysis see Alter \& Gutmann (1993).

${ }^{4}$ For an extended explanation of the conditional counting process and other multiple failure models see: Hosmer, Lemeshow, \& May (2008, pp. 287-296).
} 
the analysis, meaning that each observation after a birth has a late entry of nine months. Model fit is assessed using Akaike Information Criteria (AIC) and likelihood ratio tests. Goodness of fit is evaluated by testing the scaled Schoenfeld residuals and further investigated by visualization of the adjusted hazard functions (Grambsch \& Therneau, 1994).

The Cox regression models are adjusted for other variables known to affect fertility. The chances of natural sterility increase with age, thereby age of mother is divided into six age groups. If a child dies within the first 18 months of life, breastfeeding is ended prematurely, thereby increasing the risk of pregnancy. The survival status of the last-born child is included as a time varying variable. A variable indicating the occupational status of the father is included and divided into five occupational groups. The gender composition of surviving children is also included to account for gender preferences. The variable for surviving children is time varying, recalculated for each birth and death event. Context level effects, such as general industrialization and urbanization, are taken into account by grouping the parishes into two categories: the rural inland and the industrial and urban coastal region. Cohort is also included to capture the changes over time. The distribution of birth events by variable and model can be seen in Table 4 in the appendix.

\section{Reproductive practices}

\subsection{Cohort fertility}

Fertility started to decline in Sweden around 1880, as seen in Figure 4. It started earlier in urbanized areas, with Stockholm as a forerunner and northern Sweden as a lagger, for example in Västernorrland county (the greater Sundsvall region) where fertility did not start to decline before 1900 (Hofsten \& Lundström, 1976). Previous research has also shown that period total marital fertility rate (TMFR) rose in the 1870s, especially in the coastal parishes (Alm Stenflo, 1994). However, estimations of fertility from period TMFR have been criticized and the cohort approach promoted (Bhrolchain, 1992). In Figure 5, cohort TMFR is shown by affiliation. Over all, TMFR rose between the first and second marriage cohorts just as the period data have previously shown, while TMFR dropped by $23 \%$, from 7.6 to 5.8 in the birth cohort, indicating the start of a fertility decline. Free-church affiliates had higher TMFR than did state church affiliates in all cohorts. However, both groups follow the general pattern of increase after 1875 and a decline for the birth cohort. The generally high free-church fertility indicates that religiosity influenced fertility positively. This

has also been shown in the United states where religiosity measured as the propensity to give children a biblical name was associated with high marital fertility. On the 
other hand the same study shows a negative relationship between marital fertility and the size of liberal churches within a state (Hacker, 1999).

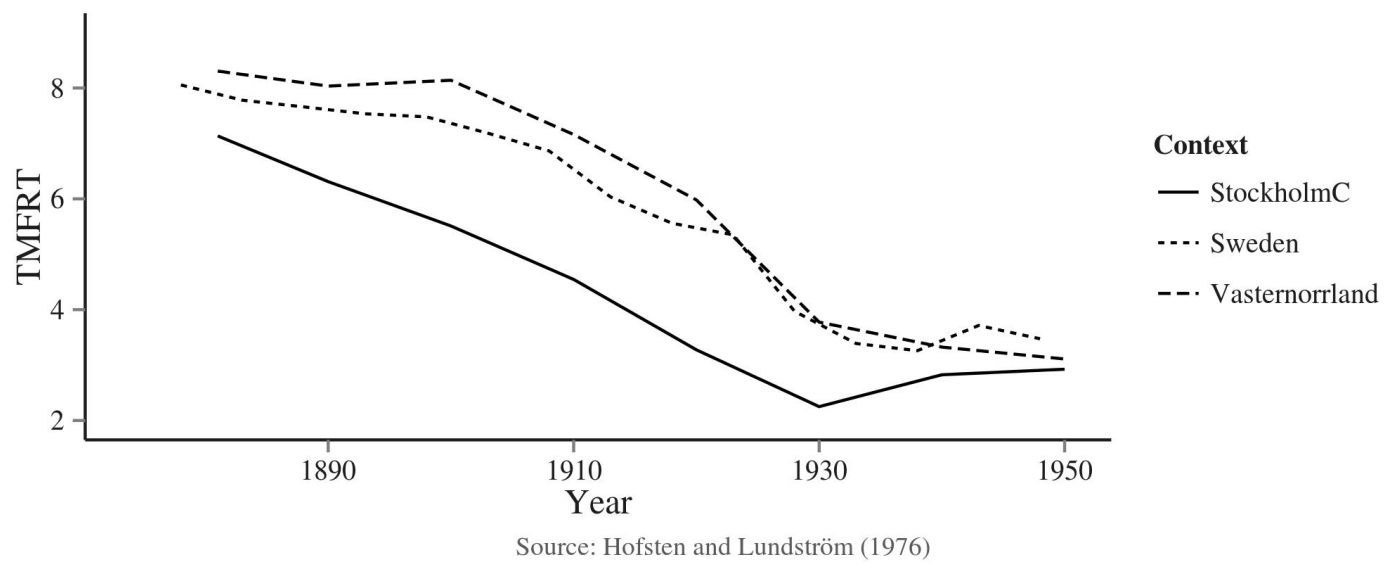

Figure 4: TMFR in Sweden, Västernorrland and Stockholm

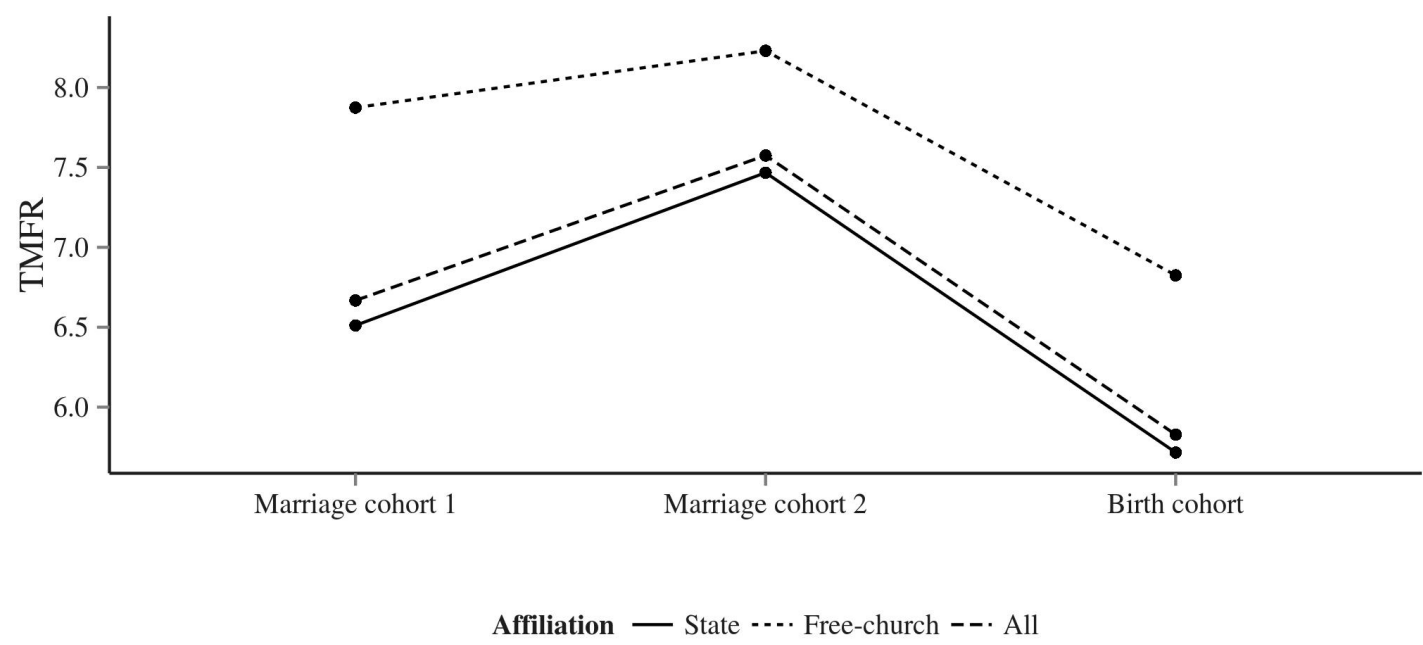

Figure 5: Cohort TMFR

Looking at age-specific marital fertility rates by affiliation (figure 6) the differences between the marriage cohorts and the birth cohort becomes clearer. Between the first and second marriage cohorts there were an increase in fertility among younger married women for all affiliations. Within the birth cohort fertility declined for state church affiliates for both younger and older married women while among the free-church affiliates fertility increased for younger women while declining for older 
women. However it is impossible to deduce to role of stopping and spacing behaviour by age-specific fertility rates alone.

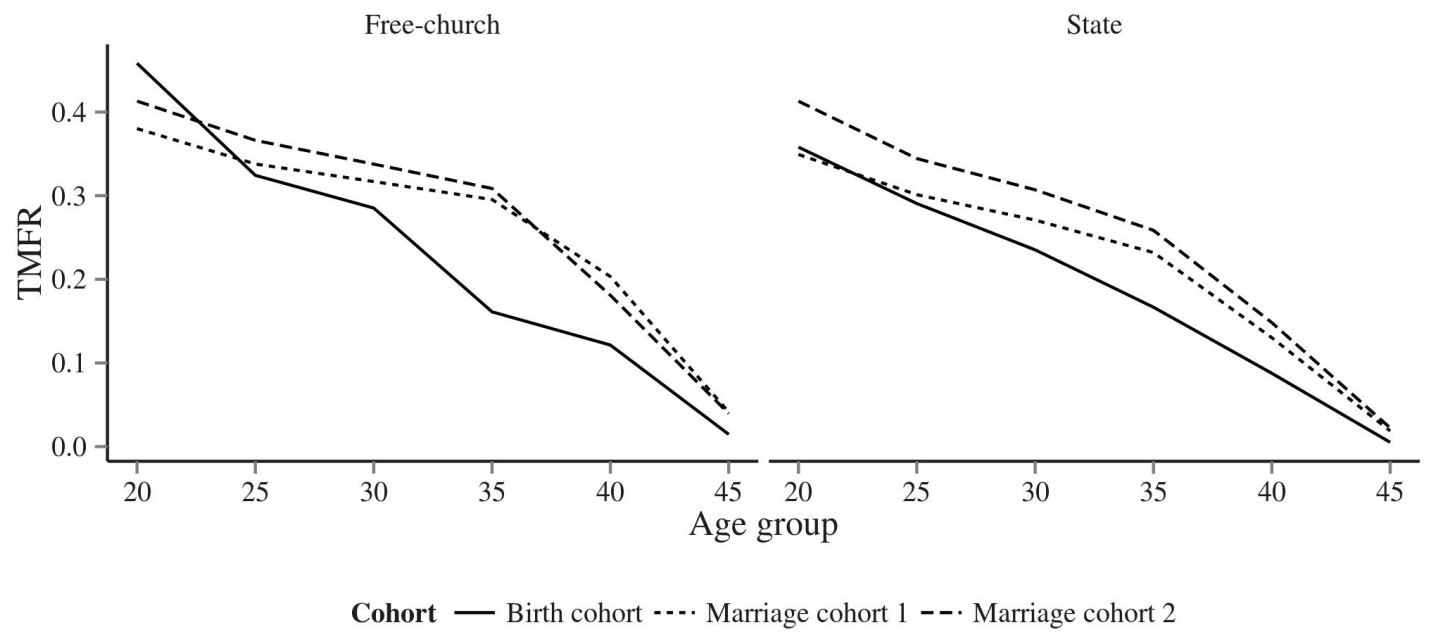

Figure 6: Age-specific Cohort TMFR

\subsection{Starting}

Focusing on descriptive measures of reproductive practices, we can only account for full reproductive life courses. Thus the sample size decreases as fewer married couples can be followed throughout their reproductive history, from the woman's 15th birthday to her 45th. Furthermore, owing to the different sampling criteria, comparisons between cohorts are tendentious. The second marriage cohort is overrepresented by couples marrying later in life, and the birth cohort does not include immigrants, meaning that younger couples are more likely to be included. For that reason, we can only consider changes in the difference between affiliations when looking at age at marriage and age at last birth.

Age at marriage was the start of married reproductive life for these couples; the averages can be seen in Figure 7 . There was no significant change over time in the difference in marriage age by affiliation. Women affiliated with a free church married earlier than did state church affiliates in both cohorts. The marriage age is around 25 in the first marriage cohort and around 24 in the birth cohort. Studies utilizing period data have shown female marriage age to be between 25-26 in the same region and period (Alm Stenflo, 1994, p. 68). The marriage age within the birth cohorts was low in comparison, owing to the selection effect caused by excluding migrants. Looking at the interval between marriage and first birth in Figure 8, we 


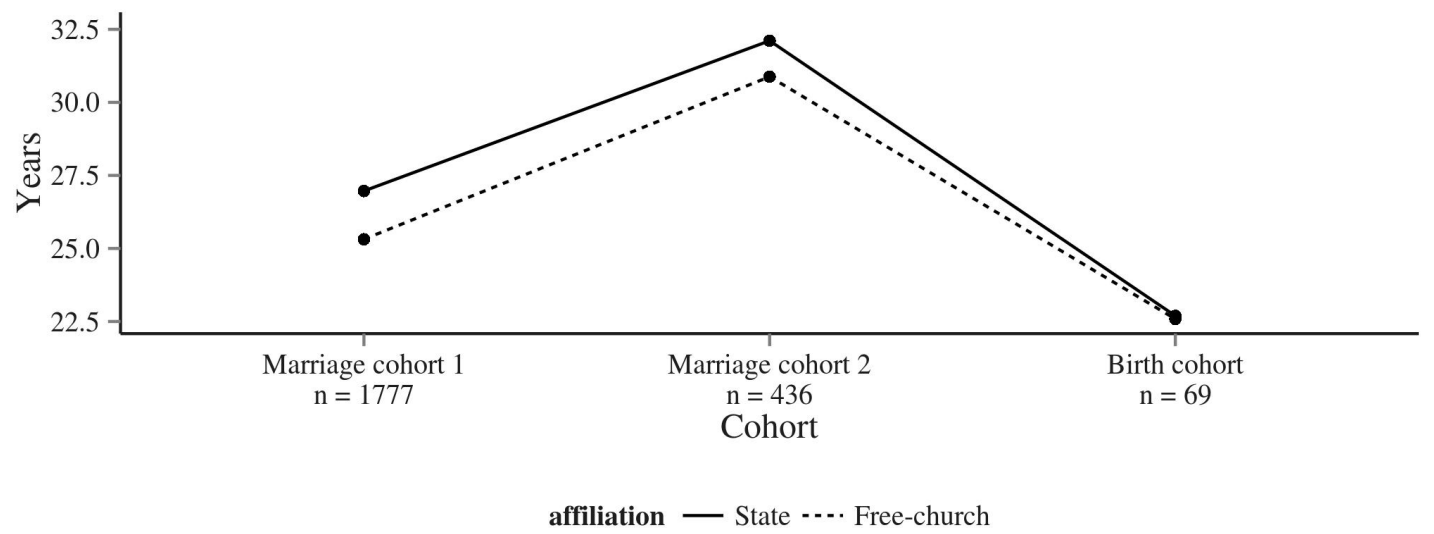

Figure 7: Women's age at first marriage

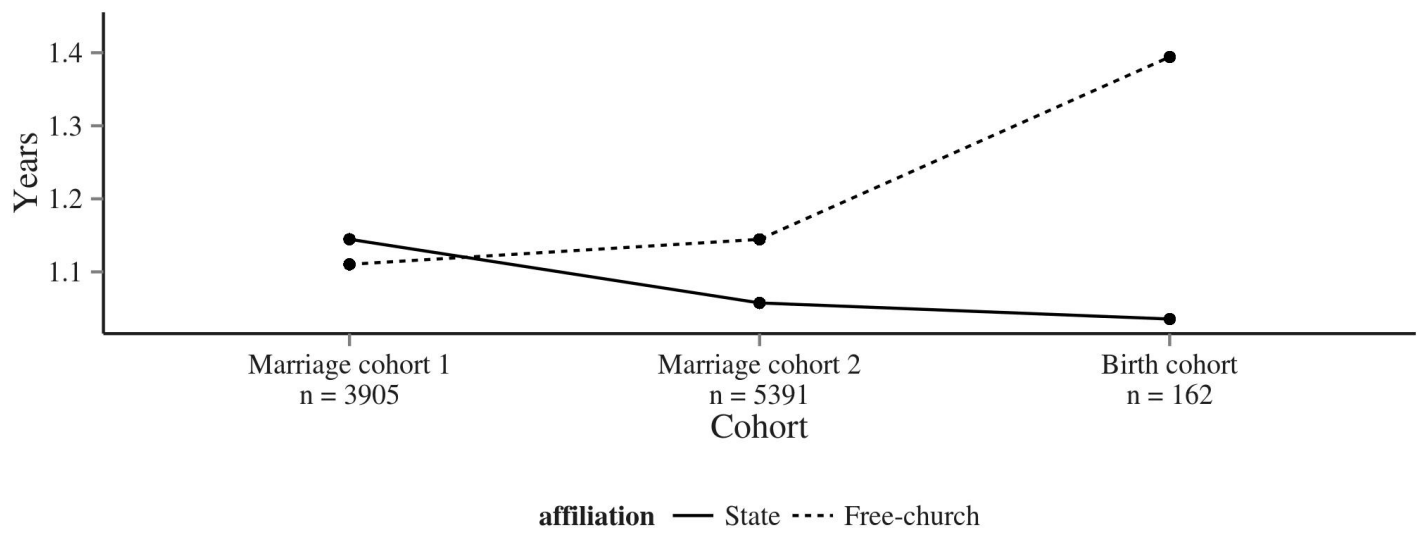

Figure 8: Interval between first birth and marriage 
do see differences in practices. Within the first marriage cohort of 1860-1874, the average time between births was 1.1 years for both free-church and state church affiliates. While the average interval remained the same between cohorts for state church affiliates, the interval lengthened for the free-church affiliates to 1.4 in the birth cohort 1869-1871. Time between marriage and first birth is dependent on practices of premarital conception. The free churches emphasize on upholding sexual morality especially when it comes to premarital relations would would lead us to expect a longer interval between marriage and first birth, which we see within the birth cohort (Kennerberg, 1996). However, it is surprising that we only find this behaviour in among the birth cohorts and not among the marriage cohorts. This seem to suggest that premarital relations was not seen as a problem, to the same extent, before the onset of fertility decline.

\subsection{Spacing and stopping}

To examine differences in spacing and stopping behaviour, we look at closed and open birth intervals. Closed intervals are followed by another birth within five years while open intervals are not. The five-year range is set to identify intentional stopping behaviour and to exclude subsequent unintentional births due to imperfect birth control methods. Figure 9 shows the average age of women at last birth. Those free-church affiliates who married before 1875 had their last child at a later age than did state church affiliates who married before 1875. This difference, however, is not found within the second marriage cohort, where they stopped at approximately the same age. Furthermore, there is a decrease in age at last birth over time, which indicates stopping behaviour. However, owing to the different sampling criteria, cross-cohort comparisons are problematic. This means that we cannot asses if the disappearance of the difference in stopping behaviour was due to state church couples stopping at a later age or free-church couples stopping at an earlier age. We can only conclude that there were no change in the relative difference in stopping age between the first marriage cohort and the birth cohort

When looking at birth intervals, we are once again not restricted to complete reproductive histories and can include all observed closed birth intervals. Figure 10 shows that there were no major differences in closed intervals by affiliation until the birth cohort 1869-1871, when the interval remained at 2.2 years for state church affiliates and increased to 3 years for free-church affiliates. This indicates that free-church couples to a greater extent than state church couples limited their fertility by waiting longer until they had another birth during the onset of fertility decline. Within the free churches contraceptives was not seen as a expectable way of controlling fertility, abstinence on the other hand, was (Kristenson, 1997). Leading to free-church couples controlling their fertility through spacing, a behaviour that 


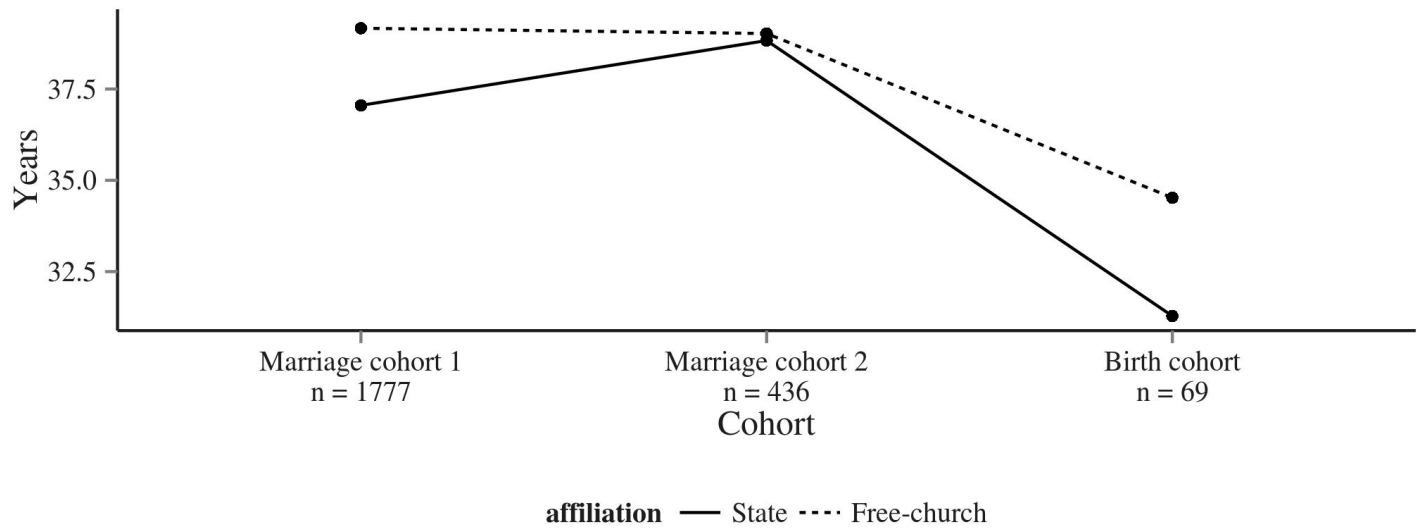

Figure 9: Women's age at last birth

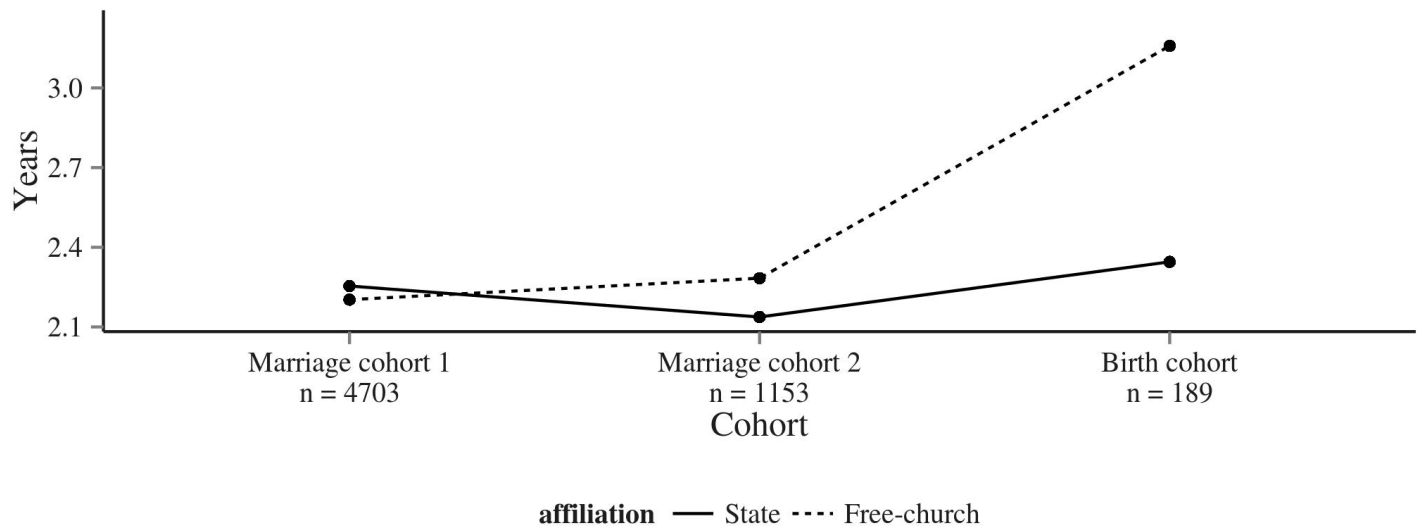

Figure 10: Interval between births 
has been found in other religious groups where contraceptives where not accepted such as the Mormons (Anderton \& Bean, 1985).

\subsection{Timing of another birth}

Owing to the small sample size of the birth cohort, it is not possible to perform any parity-specific test, but instead we take the full reproductive life course into account when analysing timing of another birth, incorporating all closed and open births after the first birth. The hazard of having another child, counted in years since the first-born child, by religious affiliation and parity is shown by the plotted Nelson-Aalen estimates in Figure 11. For both marriage cohorts, free-church affiliates had a higher risk than state church affiliates did. An increase in cumulative hazard is also shown by the higher estimates for those married after 1875 compared to the first marriage cohort. However, within the birth cohort, the estimates are lower and the affiliation difference are no longer apparent because the cumulative hazard curves have merged. These results confirm that free-church couples had higher fertility than other couples did and that these differences decreased at the start of the fertility transition. The Nelson-Aalen estimates also show that the largest change in reproductive practices occurred among the free-church affiliates.

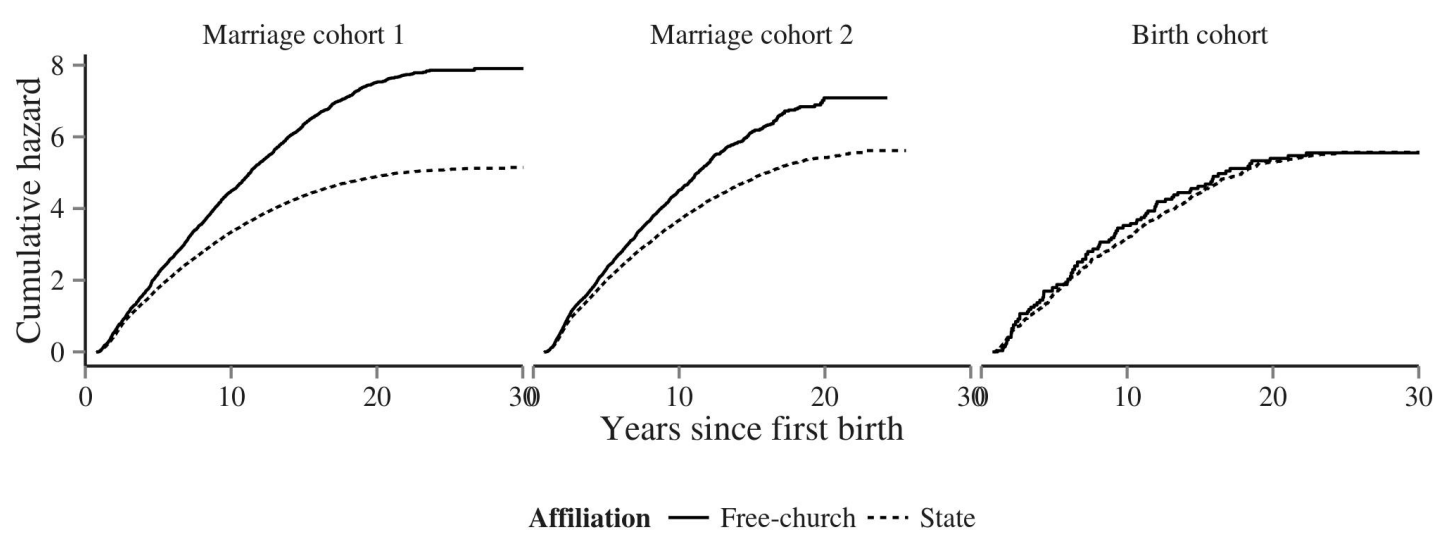

Figure 11: Nelson-Ahlen plot, Estimated cumulative hazard rate of another birth by religious affiliation.

The previous analysis indicates that there was a significant change in reproductive practices among the free-church affiliates shown by an increase in family limitation resulting in lower risk of having another child and a decline in cohort TMFR. To test these observations in a multivariate setting, we fit the data into Cox proportional hazard models; the models are built and tested incrementally. Although the test of 
the scaled Schoenfeld residuals shows non-proportionalities in some of the models for the covariates economy and occupation, stratified visualizations of the adjusted hazard functions in these covariates do not reveal any significant problems with the proportional hazard assumption. However, the indicator for the survival status of the previously born child is non-proportional, and the risk is therefore stratified by the survival status of the previously born child. Owing to these measures, we are confident in the model results.

Table 2 shows the estimated effects on the probability of having another birth for all couples and by affiliation. In the full model, the effect of free-church affiliation on the probability of having another birth is almost 21 percent higher than the effect of state church affiliation. The regression results also confirm the observation that there is a slight increase in probability between the first marriage cohort and the second cohort. Furthermore, a 13 percent reduction in probability is seen by the estimates for the birth cohort compared to the first marriage cohort. It is those in this group, who started their reproductive life courses in the late 1880s onwards and ended them, in this analysis, for the most part around 1920, who experienced the start of the fertility transition. Turning to the affiliation-specific models, the estimated effect of belonging to the birth cohort is negative and significant in both models. However, the negative effect is larger among the free-church (0.721) than among the state church affiliates (0.89).

To test differences in the effect of religious affiliation by cohort, the data are fitted to three cohort-specific models; the results are shown in Table 3. The estimated effect of free-church affiliation on the probability of having another child is highest among those married before 1875, lower for those married after 1875 and non-existent for the 1869-71 birth cohort, as the estimate is almost 1 and the effect is not significant. To test whether this reduction in effect was significant, we introduce an interaction between cohort and religious affiliation seen in the interaction model in Table 3 . The interaction model is a slightly better fit than the full model, as seen by the lower AIC and higher result for the likelihood ratio test. Moreover, the results show a significant reduction of 20 percent in the estimated effect of free-church affiliation between the first marriage cohort and the birth cohort.

Another interesting result is that there was an offspring gender preference for both sons and daughters before and after fertility started to decline. The couples married after 1875 showed a small but significant increase in probability of having another child if they only had surviving sons and/or only surviving daughters compared to having surviving children of both genders. For couples in the birth cohort, the estimated effect is much stronger: 70 percent for only daughters and 43 for only sons. The preference for a mixed gender offspring set can be clearly seen before the fertility transition, and the preference strengthened as fertility declined in society. Furthermore, the gender preference is only seen among the state church affiliates, as shown by the results of the affiliation-specific models presented in Table 2. 


\begin{tabular}{|c|c|c|c|}
\hline Variable & Full model & Free-church & State church \\
\hline \multicolumn{4}{|l|}{ Affiliation } \\
\hline - State & 1 (ref.) & & \\
\hline - Free-church & $1.201 * *$ & & \\
\hline \multicolumn{4}{|l|}{ Age group } \\
\hline$-15-19$ & 1 (ref.) & 1 (ref.) & 1 (ref.) \\
\hline$-20-24$ & $0.856 * *$ & 0.824 & $0.858 * *$ \\
\hline$-25-29$ & $0.741 * *$ & $0.701 * *$ & $0.747 * *$ \\
\hline$-30-34$ & $0.635 * *$ & $0.583 * *$ & $0.643 * *$ \\
\hline$-35-39$ & $0.466 * *$ & $0.448 * *$ & $0.469 * *$ \\
\hline$-40+$ & $0.161 * *$ & $0.149 * *$ & $0.163 * *$ \\
\hline \multicolumn{4}{|l|}{ Occupation } \\
\hline - Farmer & 1 (ref.) & 1 (ref.) & 1 (ref.) \\
\hline - Manager/White collar & 0.99 & 1.05 & 0.995 \\
\hline - Farmworker & $1.068 * *$ & 0.943 & $1.087 * *$ \\
\hline - Industrial worker & $1.11 * *$ & 0.964 & $1.135 * *$ \\
\hline - other & $1.074 * *$ & $0.889 *$ & $1.104 * *$ \\
\hline \multicolumn{4}{|c|}{ Gender of surviving children } \\
\hline - Mixed & 1 (ref.) & 1 (ref.) & 1 (ref.) \\
\hline - Only sons & $1.058 * *$ & 1.005 & $1.069 * *$ \\
\hline - Only daughters & $1.039 *$ & 0.995 & $1.049 * *$ \\
\hline - None & $1.236 * *$ & 1.219 & $1.247 * *$ \\
\hline \multicolumn{4}{|l|}{ Region } \\
\hline - Rural & 1 (ref.) & 1 (ref.) & 1 (ref.) \\
\hline - Coastal & $1.109 * *$ & $1.142 * *$ & $1.105 * *$ \\
\hline \multicolumn{4}{|l|}{ Cohort } \\
\hline - Marriage cohort 1 & 1 (ref.) & 1 (ref.) & 1 (ref.) \\
\hline - Marriage cohort 2 & $1.031 * *$ & 0.985 & $1.039 * *$ \\
\hline - Birth cohort & $0.866 * *$ & $0.721 * *$ & $0.89 * *$ \\
\hline \multicolumn{4}{|l|}{ Summary } \\
\hline - Events & 23095 & 3669 & 19426 \\
\hline - AIC & 314844.25 & 34203.86 & 260681.075 \\
\hline - Likelihood ratio test & 2304.02 & 327.259 & 1853.859 \\
\hline - Wald test & 0 & 0 & 0 \\
\hline
\end{tabular}

Table 2: Probability of having another birth for all couples and by religious affiliation, Cox proportional hazard regressions. 


\begin{tabular}{|c|c|c|c|c|}
\hline Variable & $\begin{array}{l}\text { Marriage } \\
\text { cohort } 1\end{array}$ & $\begin{array}{l}\text { Marriage } \\
\text { cohort } 2\end{array}$ & $\begin{array}{l}\text { Birth co- } \\
\text { hort }\end{array}$ & Interaction \\
\hline \multicolumn{5}{|l|}{ Affiliation } \\
\hline - State & 1 (ref.) & 1 (ref.) & 1 (ref.) & 1 (ref.) \\
\hline - Free-church & 1.044 & $1.252 * *$ & $1.255 * *$ & $1.165 * *$ \\
\hline \multicolumn{5}{|l|}{ Age group } \\
\hline$-15-19$ & 1 (ref.) & 1 (ref.) & 1 (ref.) & 1 (ref.) \\
\hline$-20-24$ & 0.934 & $0.856 * *$ & $0.822 * *$ & $0.878 *$ \\
\hline$-25-29$ & 0.763 & $0.742 * *$ & $0.74 * *$ & $0.74 * *$ \\
\hline$-30-34$ & $0.558 * *$ & $0.636 * *$ & $0.62 * *$ & $0.649 * *$ \\
\hline$-35-39$ & $0.455 * *$ & $0.467 * *$ & $0.459 * *$ & $0.473 * *$ \\
\hline$-40+$ & $0.158 * *$ & $0.162 * *$ & $0.163 * *$ & $0.147^{* *}$ \\
\hline \multicolumn{5}{|l|}{ Occupation } \\
\hline - Farmer & 1 (ref.) & 1 (ref.) & 1 (ref.) & 1 (ref.) \\
\hline - Manager/White collar & 0.991 & 0.99 & 1.031 & 0.954 \\
\hline - Farmworker & 0.865 & $1.068 * *$ & 1.045 & $1.109 * *$ \\
\hline - Industrial worker & 0.842 & $1.11 * *$ & $1.104 * *$ & $1.145^{* *}$ \\
\hline - other & 0.871 & $1.074 * *$ & 1.04 & $1.13^{* *}$ \\
\hline \multicolumn{5}{|l|}{ Gender of surviving children } \\
\hline - Mixed & 1 (ref.) & 1 (ref.) & 1 (ref.) & 1 (ref.) \\
\hline - Only sons & $1.413 * *$ & $1.058 * *$ & 1.046 & $1.058 * *$ \\
\hline - Only daughters & $1.71^{* *}$ & $1.038 *$ & 1.01 & $1.049 *$ \\
\hline - None & $3.915 * *$ & $1.236 * *$ & $1.264 * *$ & $1.191 * *$ \\
\hline \multicolumn{5}{|l|}{ Region } \\
\hline - Rural & 1 (ref.) & 1 (ref.) & 1 (ref.) & 1 (ref.) \\
\hline - Coastal & 0.91 & $1.108 * *$ & $1.092 * *$ & $1.13 * *$ \\
\hline \multicolumn{5}{|l|}{ Cohort } \\
\hline - Marriage cohort 1 & & 1 (ref.) & & \\
\hline - Marriage cohort 2 & & $1.042 * *$ & & \\
\hline - Birth cohort & & $0.894 * *$ & & \\
\hline \multicolumn{5}{|l|}{ Interactions } \\
\hline - Free-church $*$ Marriage cohort 1 & & 1 (ref.) & & \\
\hline - Free-church $*$ Marriage cohort 2 & & $0.929 * *$ & & \\
\hline - Free-church $*$ Birth cohort & & $0.802 *$ & & \\
\hline \multicolumn{5}{|l|}{ Summary } \\
\hline - Events & 623 & 23095 & 11558 & 10914 \\
\hline - $\mathrm{AIC}$ & 3885.774 & 314841.868 & 137083.951 & 138684.522 \\
\hline - Likelihood ratio test & 42.407 & 2310.402 & 1410.528 & 841.341 \\
\hline - Wald test & 0 & 0 & 0 & 0 \\
\hline
\end{tabular}

Table 3: Probability of having another birth by cohort, Cox proportional hazard regressions. 


\section{Discussion}

In the present article, we have explored reproductive practices by religious affiliation in Sundsvall 1860-1921 using individual-level longitudinal data, where we have identified free-church and state church affiliations on a family level.

As expected, couples affiliated with a free church had a higher cohort TMFR; the women married at an earlier age and stopped having children at a later age than was the case among state church couples. The Cox proportional hazard regressions also show a higher probability of having another birth for free-church couples. To become a member of a free church, you had to make an active choice and be able to show that you lived a Christian life by conforming to the moral values of the community. The use of contraceptives was deemed as inappropriate and in the absence of societal pressure to control fertility to any greater extent before the fertility transition, the religious culture of the free churches promoted large families. Furthermore the result on timing of first birth which show no differences by affiliation before fertility decline, suggests that premarital conception was not viewed more problematic among free churches affiliates than state church affiliates. Which indicates that sexual morality was not an to the same extent an issue for the free churches until fertility started to decline. In essense, these were churches with strong internal social control (Kennerberg, 1996; Larsson, 1984) that promoted reproductive practices which resulted in higher fertility before the fertility transition.

On the other hand, the analysis shows that as fertility started to decline, free-church affiliates had longer intervals between marriage and first child and waited longer until they had another child. The regression results also show a larger significant reduction in the probability of having another child over time than among state church couples, and a significant reduction in the estimated effect of free-church affiliation over time, eventually showing no significant effect of free-church affiliation. This indicates that the largest change in reproductive practices occurred among the free-church affiliates.

This would seem to be a contradiction. At the same time as free-church affiliates participated within religious settings that promoted reproductive practices leading to higher fertility before the fertility transition, they also practised birth control during the fertility decline. These were still organizations with strong social control where membership still entailed strong personal conviction. However, at this point in time societal pressures emerged to limit family sizes such as the spread of propaganda promoting the use of birth control and public debates about decency, respectability and family limitation in the Sundsvall newspapers in the 1880s (Kling, 2007; Levin, 1994). We can also see that within the free churches, birth control through abstinence was possible, even promoted over contraceptives (Hammar, 1999; Kristenson, 1997). Birth control was not inconceivable, but instead within these new religious cultures 
new gender roles emerged that promoted sexual restraint, high sexual morality, and an emphasis on the role of the woman in elevating the husband and the family to the same level of Christian morality that she maintained (Åberg, 1995; Kennerberg, 1996; Pasture, 2012). The religious culture within the free churches did not hinder family limitation but rather embraced the idea and incorporated it in their gendered religious identities.

Furthermore, the results show that people did use birth control to shape fertility outcomes before the fertility transition, as the mixed child gender preference was existent before fertility started to decline, which is in line with previous studies (Kolk, 2011; Reher \& Sandström, 2015; Sandström \& Vikström, 2015; Van Bavel, 2004a). The findings stand in contrast to studies that build upon Coale's framework, where secularization is the process that places fertility control within the calculus of conscious choice (A. J. Coale \& Watkins, 1986; Lesthaeghe \& Wilson, 1986). The results also show that an alternative perspective on secularization help us to better understand the impact of secularization on fertility decline. A perspective that not only entails an decrease in organized religion but also a process where the meaning of religion becomes challenged and changed through alternative forms of Christian associations, such as the free churches. The results then indicate that, through the growth of the free churches, old norms about the relationship between gender and reproductive practices were challenged and birth control became a way of conforming to these new ideas about manliness and femaleness. This supports previous studies emphasizing the importance of how gender relations were constructed within a certain cultural context for the fertility decline both in Sweden (Warg, 2002) and Europe (Praz, 2009; Szreter, 1993). Finally, the results contribute to the body of research that has nuanced views on religious differentials in fertility (Benz, 2006; Derosas, 2006; Hacker, 1999).

The results of the present study indicate that there was a connection between how gender was performed and perceived within a religious culture and how birth control was practised. However, if it is to be better understood, the strength of this connection must be grounded in investigations of views on family and gender within the free churches. On the other hand, the present results also raise many questions. During the second half of the 20th century, free-church families were associated with high fertility: How did reproductive practices change after the 1920s? Was there a difference compared to people with strong personal religious convictions within the Lutheran state church? How were reproductive practices perceived and performed by people within the other popular movements? The growth of the free churches has been seen as the start of a larger cultural shift in Sweden, involving the subsequent growth of secular groups such as the socialist movement and workers unions, which might be key to our understanding of the fertility transition in Sweden. 


\section{Acknowledgements}

The authors wish to thank Sofia Kling for allowing us to use her research data, originally retrieved in 2005 from the Demographic Database. The authors are grateful to Per-Olof Grönberg, whose work with parsing of affiliation from parish registers made this study possible. The authors are also thankful for the feedback provided by session discussant and session participants, at the 38th meeting of the Social Science History Association Meeting (SSHA), Chicago, Illinois, USA, 21-24 November 2013, and at the Conference of the European Society of Historical Demography, Alghero, Italy, 25-27 September 2014. Finally, the authors would like to thank Katherine Lynch for her feedback on an early version of the paper in 2013 and the two anonymous reviewers who provided important suggestions that improved this paper.

\section{Notes}

The underlying research materials for this article can be accessed at https://github. com/junkka/freechurchfertility/.

\section{References}

Alm Stenflo, G. (1994). Demographic description of the skelleftea and sundsvall regions during the 19th century. Umeå: Demographic Data Base [Demografiska databasen], Univ.

Alter, G., \& Gutmann, M. (1993). Family reconstitution as event history analysis. In D. S. Reher \& R. Schofield (Eds.), Old and new methods in historical demography. Oxford: Clarendon Press.

Anderton, D. L., \& Bean, L. L. (1985). Birth spacing and fertility limitation: A behavioral analysis of a nineteenth century frontier population. Demography, 22(2), 169-183. http://doi.org/10.2307/2061176

Andrae, C.-G., \& Lundkvist, S. (1998). SND0209 folkrörelsearkivet 1881-1950 [SND0209 population movment archive 1881-1950]. Svensk Nationell Databastjänst [Swedish National Database Service]. Retrieved from http://snd.gu.se/sv/catalogue/ study/SND0209 
Åberg, I. (1995). Att studera kvinnor i de tidiga väckelserörelserna [to study women in the early revivalmovement]. In Kulturdagar $i$ bonäs bygdegård [culture days in bonäs bygdegård] (Vols. 1994, s. 23-32). Mora: Stiftelsen Bonäs bygdegård.

Bäckström, A. (1999). När tros- och värderingsbilder förändras : En analys av nattvards- och husförhörssedens utveckling i sundsvallsregionen 1805-1890 [when faith and values change: An analysis of communion and catechetical examination customs in the sundsvall region 1805-1890]. Stockholm: Verbum.

Beckford, J. A. (2003). Social theory and religion. Cambridge: Cambridge Univ. Press.

Bengtsson, T., \& Dribe, M. (2006). Deliberate control in a natural fertility population: Southern sweden, 1766-1864. Demography, 43(4), 727-746. http://doi.org/10.2307/4137215

Benz, E. (2006). Family limitation among political catholics in baden in 1869. In R. Derosas \& F. van Poppel (Eds.), Religion and the decline of fertility in the western world (pp. 21-39). Springer Netherlands.

Bhrolchain, M. N. (1992). Period paramount? A critique of the cohort approach to fertility. Population and Development Review, 18(4), 599-629. http://doi.org/10.2307/1973757

Bhrolcháin, M. N. (2011). Tempo and the TFR. Demography, 48(3), 841-861. http://doi.org/10.1007/s13524-011-0033-4

Broström, G. (2014). Female reproduciton and population growth sweden 1749-2013. In. Presented at the First conference of the european society of historical demography, Alghero, Sardinia.

Brown, C. G. (2009). The death of christian britain: Understanding secularisation, 1800-2000. Taylor \& Francis.

Butler, J. (2004). Undoing gender. Taylor \& Francis.

Carter, A. T. (1995). Agency and fertility: For an ethnography of practice. In S. Greenhalgh, Situating fertility (pp. 55-85). Cambridge University Press.

Coale, A. (1973). The demographic transition reconsidered. In International population conference, liège, 1973, vol. 1 (pp. 53-72). Liège: International Union for the Scientific Study of Population.

Coale, A. J., \& Watkins, S. C. (1986). The decline of fertility in europe: The revised proceedings of a conference on the princeton european fertility project, 1979. University Press.

Davidoff, L., \& Hall, C. (1987). Family fortunes : Men and women of the english middle class, 1780-1850. Chicago: University of Chicago Press. 
Derosas, R. (2006). Between identity and assimilation: Jewish fertility in nineteenthcentury venice. In R. Derosas \& F. van Poppel (Eds.), Religion and the decline of fertility in the western world (pp. 21-39). Springer Netherlands.

Gauvreau, D. (2006). Religious diversity and the onset of the fertlity transition: Canada, 1870-1900. In R. Derosas \& F. van Poppel (Eds.), Religion and the decline of fertility in the western world (pp. 21-39). Springer Netherlands.

Grambsch, P. M., \& Therneau, T. M. (1994). Proportional hazards tests and diagnostics based on weighted residuals. Biometrika, 81(3), 515-526. http://doi.org/10.2307/2337123

Greenhalgh, S. (1995). Anthropology theorizes reproduction : Intergrating practice, political economic, and feminist perspectives. In S. Greenhalgh, Situating fertility (pp. 3-28).

Gustavsson, A. (1985). Religiösa väckelserörelser $i$ norden under 1800- och 1900talen: Aktuell forskning presenterad vid ett symposium [religious revival movements in the nordic counties during the 18th and 19th centuries: Current research presented at a symposium]. Lund: Centrum för religionsetnologisk forskning (distr.).

Hacker, J. D. (1999). Child naming, religion, and the decline of marital fertility in nineteenth-century america. The History of the Family, 4(3), 339-365. http://doi.org/10.1016/S1081-602X(99)00019-6

Hammar, I. (1999). Emancipation och religion : Den svenska kvinnorörelsens pionjärer $i$ debatt om kvinnans kallelse ca 1860-1900 [emancipation and religion: Pioneer within the swedish womens movements and the female calling 1860-1900 ]. Stockholm: Carlsson.

Heaton, T. B. (1986). How does religion influence fertility?: The case of mormons. Journal for the Scientific Study of Religion, 25(2), 248-258. http://doi.org/10.2307/1385480

Henry, L. (1961). Some data on natural fertility. Eugenics Quarterly, 8(2), 81-91. http://doi.org/10.1080/19485565.1961.9987465

Hinde, A. (1998). Demographic methods. London: Arnold.

Hofsten, E. A. G. von, \& Lundström, H. (1976). Swedish population history: Main trends from 1750 to 1970. Statistiska centralbyrån : [LiberFörlag].

Hosmer, D. W., Lemeshow, S., \& May, S. (2008). Applied survival analysis (electronic version]: Regression modeling of time-to-event data. Hoboken, N.J.: WileyInterscience. Retrieved from http://dx.doi.org/10.1002/9780470258019

Johansson, E. (1997). Kris och förnyelse : Kyrkolivet sedan 1870-talet [crisis and renewal: Churchlife since the 1870s]. In Sundsvalls historia / redaktör: Lars-göran 
tedebrand. d. 2 (Vols. S. 393-413). Sundsvalls historia / redaktör: Lars-Göran Tedebrand. D. 2 Sundsvall : Stadshistoriska komm., 1997.

Kennerberg, O. (1996). Innanför eller utanför : En studie av församlingstukten $i$ nio svenska frikyrkoförsamlingar = [inside or outside] : [A study of church discipline in nine swedish free churches]. Örebro: Libris.

Kling, S. (2007). Vi våga ej helt leva: barnbegänsning, sexualitet och genus under den svenska fertilitetstransitionen [We Dare Not Fully Live: Birth Control, Sexuality, and Gender During the Swedish Fertility Transition]. Umeå Universitet.

Kling, S. (2010). Reproductive health, birth control, and fertility change in sweden, circa 1900-1940. The History of the Family, 15(2), 161-173. http://doi.org/10.1016/j.hisfam.2010.01.001

Knodel, J. E. (1974). The decline of fertility in germany, 1871-1939. Princeton, N.J: Princeton University Press.

Kok, J., \& Van Bavel, J. (2006). Stemming the tide. denomination and religiousness in the dutch fertility transition, 1845-1945. In R. Derosas \& F. van Poppel (Eds.), Religion and the decline of fertility in the western world (pp. 83-105). Springer Netherlands.

Kolk, M. (2011). Deliberate birth spacing in nineteenth century northern sweden. European Journal of Population / Revue Européenne de Démographie, 27(3), 337-359. http://doi.org/10.1007/s10680-011-9228-Z

Kristenson, N. (1997). Rädda familjen: Kristen opinionsbildning i befolkningspolitiska och sexualetiska frägor under 1930-talet [Save the family: Christian advocacy in population politics and secuality issues during the 1930s]. Uppsala University.

Kyrkoskrifningskomitén. (1891). Underdånigt betänkande [humble report]. Stockholm: Nordstedt \& söner.

Larsson, M. (1984). Fruktsamhetsmönster, produktionsstruktur och sekularisering: en jämförelse mellan 69 härader vid 1800-talets slut [Fertility patterns, production structure and secularization: a comparison between 69 hundreds at the end of the 19th century]. Minab/Gotab.

Lesthaeghe, R. (1980). On the social control of human reproduction. Population and Development Review, 6(4), 527-548. http://doi.org/10.2307/1972925

Lesthaeghe, R., \& Surkyn, J. (1988). Cultural dynamics and economic theories of fertility change. Population and Development Review, 14(1), 1-45. http://doi.org/10.2307/1972499

Lesthaeghe, R., \& Wilson, C. (1986). Modes of production secularization and the pace of the fertility decline in western europe 1870-1930. In A. J. Coale \& S. C. 
Watkins (Eds.), The decline of fertility in europe: The revised proceedings of a conference on the princeton european fertility project, 1979. University Press.

Levin, H. (1994). Masken uti rosen : Nymalthusianism och födelsekontroll i sverige 1880-1910 : Propaganda och motstand [the worm in the rose: Neomalthusianism and birth control in sweden 1880-1910]. Stockholm ; B. Östlings bokförl. Symposion.

Lindberg, A. (1985). Väckelse, frikyrklighet, pingströrelse : Väckelse och frikyrka frän 1800-talets mitt till nutid [awakening, free church ecclesiasticism, pentecostal movement: Awakening and free churches from the mid 19th century to the present]. Ekerö: Kaggeholms folkhögsk.

Livi-Bacci, M. (1986). Social-group forerunners of fertility control in europe. In A. J. Coale \& S. C. Watkins (Eds.), The decline of fertility in europe: The revised proceedings of a conference on the princeton european fertility project, 1979. University Press.

Lockridge, K. A. (1983). The fertility transition in Sweden: a preliminary look at smaller geographic units, 1855-1890. Demographic Data Base, Umeå University.

Lundkvist, S. (1977). Folkrörelserna $i$ det svenska samhället 1850-1920 : [The popular movements in swedish society, 1850-1920]. Uppsala: Univ.

Lundkvist, S. (1980). The popular movements in swedish society, 1850-1920. Scandinavian Journal of History, 1980 (5), s. 219-238.

Lynch, K. A. (2006). Theoretical and analytical approaches to religious beliefs, values, and identities during the modern fertility transition. In R. Derosas \& F. van Poppel (Eds.), Religion and the decline of fertility in the western world (pp. 21-39). Springer Netherlands.

Malthus, T. R. (1926). First essay on population 1798. London: McMillan.

McLeod, H. (2000). Secularisation in western europe: 1848 - 1914. MacMillan Press.

McQuillan, K. (1999). Culture, religion, and demographic behaviour: Catholics and lutherans in alsace. McGill-Queen's Press - MQUP.

McQuillan, K. (2006). The evolution of religious differences in fertility: Lutherans and catholics in alsace, 1750-1860. In R. Derosas \& F. van Poppel (Eds.), Religion and the decline of fertility in the western world (pp. 21-39). Springer Netherlands.

Pasture, P. (2012). Beyond the feminization thesis. gendering the history of christianity in the nineteenth and twentieth centuries. In P. Pasture \& J. Art, Beyond the feminization thesis: Gender and christianity in modern europe. Leuven University Press.

Praz, A.-F. (2006a). Ideologies, gender and school policy: A comparative study of two swiss regions (1860-1930). Paedagogica Historica, 42(3), 345-361. http://doi.org/10.1080/00309230600622741 
Praz, A.-F. (2006b). State institutions as mediators between religion and fertility: A comparison of two swiss regions, 1860-1930. In R. Derosas \& F. van Poppel (Eds.), Religion and the decline of fertility in the western world (pp. 21-39). Springer Netherlands.

Praz, A.-F. (2007). Four swiss villages, 1860-1930: Putting gender back into historical demography. Gender \& History, 19(2), 242-259. http://doi.org/10.1111/j.14680424.2007.00474.x

Praz, A.-F. (2009). Religion, masculinity and fertility decline. The History of the Family, 14(1), 88-106. http://doi.org/10.1016/j.hisfam.2009.01.001

Prentice, R. L., Williams, B. J., \& Peterson, A. V. (1981). On the regression analysis of multivariate failure time data. Biometrika, 68(2), 373-379. http://doi.org/10.1093/biomet/68.2.373

R Core Team. (2014). R: A language and environment for statistical computing. Vienna, Austria: R Foundation for Statistical Computing. Retrieved from http: //www.R-project.org/

Reher, D. S., \& Sandström, G. (2015). Dimensions of rational decision-making during the demographic transition; aranjuez (spain) revisited. Historical Life Course Studies, 2, 20-26. Retrieved from http://hdl.handle.net/10622/23526343-2015-0002? locatt $=$ view $\% 3$ Amaster

Sandström, G., \& Vikström, L. (2015). Sex preference for children in german villages during the fertility transition. Population Studies, 69(1), 57-71. http://doi.org/10.1080/00324728.2014.994667

Schellekens, J., \& Poppel, F. van. (2006). Religious differentials in marital fertility in the hague (netherlands) 1860-1909. Population Studies, 60(1), 23-38. http://doi.org/10.2307/27643363

Sills, D. L. (1968). Voluntary associations. II. sociological aspects. International encyclopedia of the social sciences. Retrieved from http://www.encyclopedia.com/ doc/1G2-3045001312.html

Szreter, S. (1993). The idea of demographic transition and the study of fertility change: A critical intellectual history. Population and Development Review, $19(4)$, 659-701. http://doi.org/10.2307/2938410

Therneau, T. M. (2014). A package for survival analysis in s. Retrieved from http://CRAN.R-project.org/package=survival

Therneau, T. M., \& Grambsch, P. M. (2000). Modeling survival data: Extending the cox model. New York: Springer.

Van Bavel, J. (2004a). Deliberate birth spacing before the fertility transition in europe: Evidence from nineteenth-century belgium. Population Studies, 58(1), 
95-107. http://doi.org/10.2307/4148250

Van Bavel, J. (2004b). Diffusion effects in the european fertility transition: Historical evidence from within a belgian town (1846-1910). European Journal of Population / Revue Européenne de Démographie, 20(1), 63-85. http://doi.org/10.2307/20164254

Van Bavel, J., \& Kok, J. (2010). A mixed effects model of birth spacing for pre-transition populations. The History of the Family, 15(2), 125-138. http://doi.org/10.1016/j.hisfam.2009.12.004

Vikström, P., Edvinsson, S., \& Brändström, A. (2002). Longitudinal databases sources for analyzing the life-course: Characteristics, difficulties and possibilities. History and Computing, 14(1), 109-128. http://doi.org/10.3366/hac.2002.14.1-2.109

Warg, S. (2002). Familjen i gruvmiljö: migration, giftermålsmönster och fertilitet $i$ norrbottnisk gruvindustri 1890-1930 [The family in a mining environment: migration, marriage patterns and fertility within Northern Swedish mining industry 1890-1930]. Umeå: Demografiska databasen, Univ.

Watkins, S. C. (1986). Conclusions. In A. J. Coale \& S. C. Watkins (Eds.), The decline of fertility in europe: The revised proceedings of a conference on the princeton european fertility project, 1979. University Press.

Zeileis, A., \& Grothendieck, G. (2005). Zoo: S3 infrastructure for regular and irregular time series. Journal of Statistical Software, 14(6), 1-27. Retrieved from http://www.jstatsoft.org/v14/i06/ 
11 Appendix 


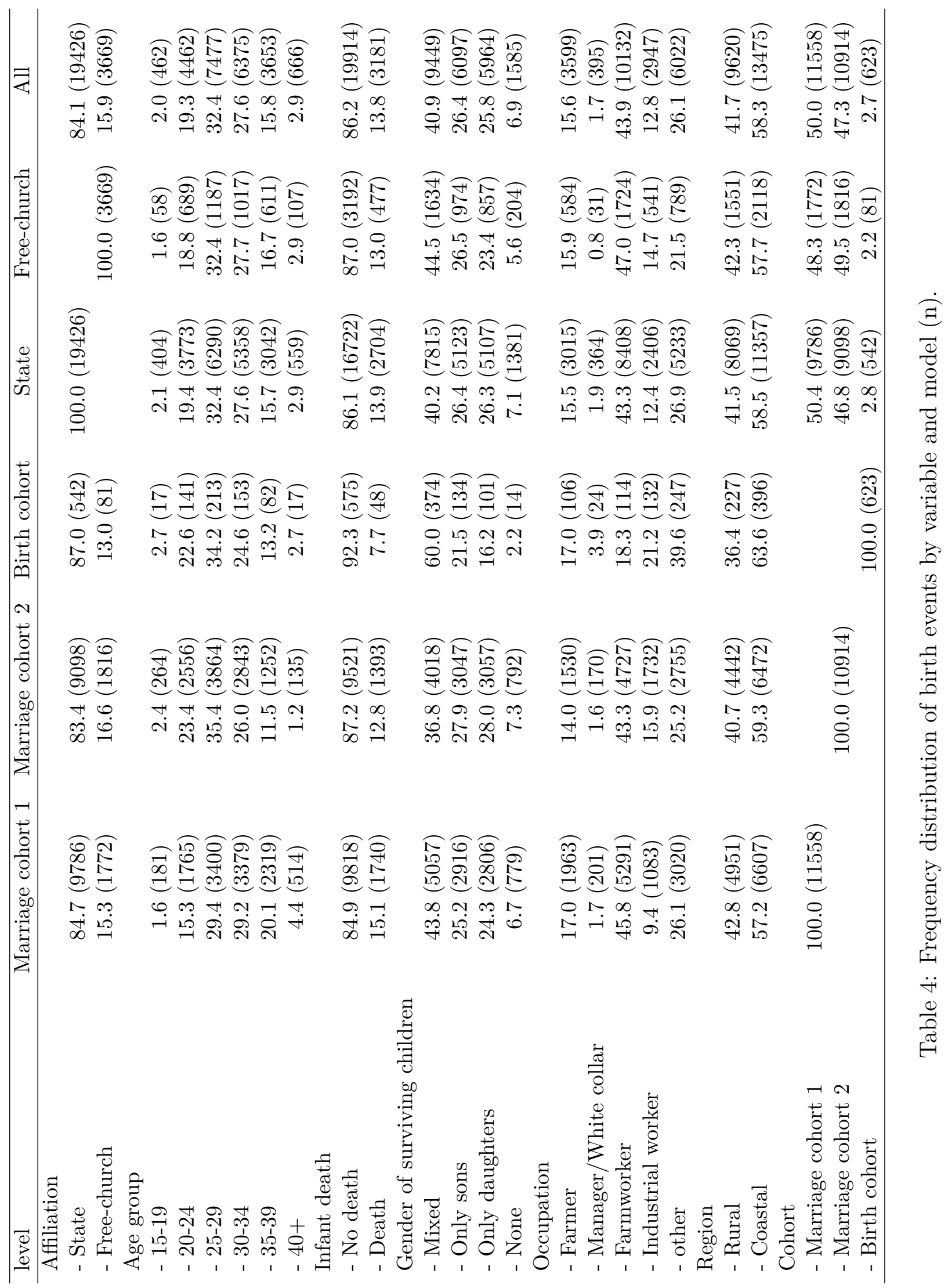

